\section{GGE Biplot Analysis of Genotype-by- environment Interactions for Melon Fruit Yield and Quality Traits}

\author{
Sat Pal Sharma and Daniel I. Leskovar \\ Texas A\&M AgriLife Research Center, Texas A\&M University, Uvalde, TX \\ 78801
}

\author{
Kevin M. Crosby \\ Department of Horticultural Sciences, Texas A\&M University, College \\ Station, TX 77842
}

\section{A.M.H. Ibrahim \\ Department of Soil and Crop Sciences, Texas A\&M University, College Station, TX 77842}

Additional index words. ascorbic acid, $\beta$-carotene, Cucumis melo, firmness, muskmelon, SSC, stability

\begin{abstract}
The stability of yield and quality traits in nine orange-fleshed melon (Cucumis melo $\mathbf{L}$.) genotypes was studied over nine environments in south-central Texas (College Station, Uvalde, and Weslaco) over 3 years (2010, 2011, and 2012). Besides yield traits, fruit -quality components such as soluble solids content (SSC), $\beta$-carotene, and fruit firmness were also measured. Data were subjected to the combined analysis of variance and trait stability by GGE Biplot. The significant genotype-by-location interactions for yield traits demonstrated the potential to develop location-specific cultivars. However, the temporal fluctuations in productivity emphasized the need to select for stability over several years in potential cultivars for the target environments. Cultivar Mission was confirmed as the most stable and average performing genotype for marketable yield and quality traits at all locations. Uvalde was identified as the ideal location for selecting generally adapted genotypes for south-central Texas. Biplot analysis indicated that Orange Dew was the highest mean performing genotype for SSC. The hybrid Oro Duro, followed by TAMU 146, ranked highest for mean and stability of $\beta$-carotene content, but it ranked lowest for fruit firmness. TAMU Orange Casaba exhibited specific adaptation, producing the highest mean fruit yield at Weslaco, while Journey had the highest fruit yield at College Station and Uvalde. Understanding of genotype-by-environment interactions for multiple traits in melon is critical for developing cultivars with high mean performance and stability in target growing environments.
\end{abstract}

Muskmelon exhibits a wide variability for vegetative traits, fruit morphology, sweetness, and climatic adaptations for yield and fruit quality ( $\mathrm{Li}$ et al., 2006). Previous reports have attributed the lack of widely adapted cultivars of muskmelon to its extreme sensitivity to environmental variations and genotype-by-environment $(\mathrm{G} \times \mathrm{E})$ interac-

Received for publication 26 Nov. 2019. Accepted for publication 21 Jan. 2020.

Published online 28 February 2020

This project was supported by the Texas Department of Agriculture (TDA No. 504610-80980), "Production and Marketing Strategies for Melons and Artichokes." Cultivar seeds were supplied by Seminis and Sakata Seeds.

We are thankful to Carrie Hensarling, Manuel Figueroa-Pagán, Juan Esquivel, and Kilsun Yoo for their technical assistance in the field and laboratory work.

D.I.L. is the corresponding author. E-mail: d-leskovar@ tamu.edu.

This is an open access article distributed under the CC BY-NC-ND license (https://creativecommons. org/licenses/by-nc-nd/4.0/). mation is available on quality traits (Paris et al., 2008), though some reports on yield and component traits from India are available (Dhakare and More, 2008; Yadav and Ram, 2010).

Sweetness, flavor, texture and phytonutrient levels of $\beta$-carotene and vitamin $C$ in flesh tissue are the determinants of fruit quality in muskmelon (Lester, 2008). Orange-fleshed muskmelons are known for their unique flavor and high sugar levels. Increased awareness about the benefits of healthful foods have earned melons a reputation as an excellent source of health promoting phytonutrients (Lester, 2006), though consumer preference is still largely determined by sweetness, aroma, and texture. Thus, selecting cultivars for high productivity, acceptable sweetness, flesh color, firmness, sensory traits, and a high amount of $\beta$-carotene and vitamin $C$ has been a great challenge for muskmelon breeders.

Soluble solids content (SSC) is a reliable indicator of quality that has been routinely used by breeders to screen germplasm for sweetness (Villanueva, 2004). Li et al. (2006) noted that soluble sugars account for more than $97 \%$ of the SSC in maturing muskmelon fruits, with sucrose accounting for nearly $50 \%$ of all sugars. As per the U.S. Department of Agriculture (USDA) standards, a high-quality muskmelon fruit should have a SSC ranging from $9 \%$ to $11 \%$ (Kultur et al., 2001). Muskmelon SSC varies with climate (Bouwkamp et al., 1978), location (Kultur et al., 2001), genotype, and crop management practices (Bhella, 1985). Edmonds and McFall (1927) observed that soluble solids were higher in a year with sunny and moderately cool conditions than in a year with cloudy days with moderately high temperatures and frequent rains. At Salisbury, MD, Bouwkamp et al. (1978) reported that high respiration rates due to increased fruit temperature through enhanced accumulated solar radiation $6 \mathrm{~d}$ before harvest might have resulted in decreased SSC in nine of 16 cultivars studied; whereas rainfall reduced the SSC in three cultivars.

Orange-fleshed muskmelons, cantaloupes (Cucumis melo L., reticulatus group), and honey dews (Cucumis melo L., inodorus group) are excellent sources of carotenoids (Pitrat, 2016). Crosby et al. (2007) reported that melon cultivars TAM Uvalde and Mission had more than $36 \mu \mathrm{g} \cdot \mathrm{g}^{-1}$ of total carotenoids. Lester and Eischen (1996) observed a significant impact of genotype-byenvironment interactions on $\beta$-carotene content of melon fruit and reported a decrease in $\beta$-carotene for the genotype Cruiser when grown in a fine sandy soil $\left(15.1 \mu \mathrm{g} \cdot \mathrm{g}^{-1}\right)$ compared with silty clay loam $\left(18.2 \mu \mathrm{g} \cdot \mathrm{g}^{-1}\right)$, while the content was similar for the genotype Primo $\left(18.1 \mu \mathrm{g} \cdot \mathrm{g}^{-1}\right)$ in both soils. Thus, the amount of $\beta$-carotene in fruits may vary according to the genotype, environment (i.e., climate and soil conditions), and $\mathrm{G} \times \mathrm{E}$ interactions.

Muskmelon ranks in the top three among the nine most consumed fresh fruits in the 
United States for supplying daily requirements of ascorbic acid. Park et al. (2006) reported that accumulation of ascorbic acid is sensitive to genotype-by-environment interaction. This trend was evident from differential response of this trait when grown at different locations, such as in Weslaco in the lower Rio Grande Valley and Uvalde in the Wintergarden region of Texas. All genotypes tested produced higher levels of ascorbic acid at Uvalde than at Weslaco. The ascorbic acid content ranged from less than $15 \mu \mathrm{g} \cdot \mathrm{g}^{-1}$ in many wild types, and some commercial cantaloupes and honeydews to $250-350 \mu \mathrm{g} \cdot \mathrm{g}^{-1}$ in genotypes such as TAM Dulce, TAM Uvalde, Mission, and TXC 2015 (Crosby et al., 2007). From the previous studies, it can be recognized that melon quality is very sensitive to both temporal and spatial environmental variations. Thus, genotypes rich in phytonutrients and with stability over diverse environments would be of great value for breeding new, high-quality melon cultivars.

Various approaches are available to analyze multienvironment genotype evaluation data (Kang, 2002). In the $\mathrm{G} \times \mathrm{E}$ studies, breeders used to focus only on yield traits, due to the complexity of data analysis (Yan and Kang, 2002). However, the advances in statistical models and analysis software have facilitated multitrait analysis (Yan et al., 2000). GGE Biplot software gives a graphical representation of $G$ and $G \times E$ effects simultaneously and thus allows researchers to concentrate mainly on the typically obscure $\mathrm{G}$ and $\mathrm{G} \times \mathrm{E}$ components. GGE Biplot can be used to evaluate the average yield and stability of a genotype as compared with others in the trial, rank environments based on ability to differentiate genotype performance, distinguish a genotype having best performance in a particular environment, and identify mega-environments within a target region based on the specifically adapted genotypes (Yan and Kang, 2002).

Due to the ubiquitous presence of $\mathrm{G} \times \mathrm{E}$ interaction effects and the availability of wide variation in melons for the traits of interest, we hypothesized that some genotypes would give differential responses for yield and quality traits across the different environments. The specific aim of the study was to evaluate nine melon genotypes, including five commercial cultivars and four elite breeding lines, grown in nine environments comprising three locations and 3 years. Estimates of $\mathrm{G} \times \mathrm{E}$ interaction should be helpful to identify breeding lines and cultivars that would be high yielding and possess good quality, including enhanced levels of phytochemicals, over different environments.

\section{Materials and Methods}

\section{Experimental details}

Five commercial cultivars (Mission, Journey, Orange Dew, Oro Duro, and Sol Real) and four advanced breeding lines (TAMU 146, TAMU Orange Casaba, TAMU F39, and TAMU 1405) from the melon breeding program at Texas A\&M University were evaluated in this study (Table 1). Genotypic evaluations were conducted at College Station (lat. $30^{\circ} 36^{\prime \prime} \mathrm{N}$, long. $96^{\circ} 18^{\prime \prime} \mathrm{W}$ ), Uvalde (lat. 29 $13^{\prime \prime} \mathrm{N}$, long. 99 $45^{\prime \prime} \mathrm{W}$ ), and Weslaco (lat. $26.12^{\circ} \mathrm{N}$, long. $98.0^{\circ} \mathrm{W}$ ) in Texas during 2010, 2011, and 2012. Soil textures of College Station, Weslaco, and Uvalde were sandy loam, sandy clay loam, and clay, respectively. The cumulative rainfall and mean minimum and maximum temperatures and average relative humidity $(\mathrm{RH})$ across the 2010, 2011, and 2012 seasons are given in Table 2 . Thus the locations were representative of different soil types and climatic conditions

The experiment was laid out as a randomized complete block design with four replications of nine melon genotypes each. Seeds were planted on raised beds $(2.03 \mathrm{~m}$ between, $0.30 \mathrm{~m}$ within row spacing) covered with black plastic mulch. Planting dates are given in Table 2. The crop was irrigated with a subsurface drip tape (Netafim, $1.14 \mathrm{~L} \cdot \mathrm{h}^{-1}, 30$ $\mathrm{cm}$ emitter spacing) placed at $15-\mathrm{cm}$ depth. The irrigation was applied based on the daily crop evapotranspiration (ETc) as described in Sharma et al. (2014).

Insecticide (thiamethoxam, Actara 25 WG; Syngenta, Greensboro, NC), acaricide (Spiromesifen, Oberon 2 SC; Bayer Crop Science, Research Triangle, NC), and fungicide (Trifloxystrobin, Flint 50 WG; Bayer Crop Science) were applied at label rates to control white flies (Bemisia tabaci Gennadius) and leaf miner (Liriomyza sativae Blanch.), mites (Tetranychus spp.), and powdery mildew (Podosphaera xanthii Schlecht.), respectively. Other practices were consistent with the recommended cultural practices for the regions (Sharma et al., 2019).

Fruit yield and component traits. Fruits were harvested at half when an abscission ring starts developing around the stem, to full slip stage when an abscission ring develops completely around the stem. At each harvest, fruits were counted and graded according to the U.S. commercial trade standards (9-, 12-, 15-, 18-count per 18-kg carton). Fruits that were cracked, damaged, rotten, misshapen, and below commercial categories were grouped under the nonmarketable category. Fruit number per plant $(\mathrm{FN})$, average fruit weight $(\mathrm{FW} ; \mathrm{kg})$, marketable fruit yield (MFY; $\mathrm{t} \cdot \mathrm{ha}^{-1}$ ), and total fruit yield (TFY; $\mathrm{t} \cdot \mathrm{ha}^{-1}$ ) were recorded. FN was recorded by counting all fruits from the plot divided by total number of plants. FW was recorded by dividing the total yield by the total number of fruits harvested.

Fruit quality. Fruit quality parameters were determined on three 9- or 12-count class fruits from each plot. Fruits were cut at the equatorial position, and firmness was measured on the mesocarp tissue at three random locations per fruit using a digital force meter (DFM 10; Chatillon, Greensboro, NC), and soluble solids content (SSC) of the mesocarp tissue $(\approx 1 \mathrm{~cm}$ from the rind) was measured with a digital refractometer (PR-101; Atago

Table 1. Characteristics of the genotypes included in the study.

\begin{tabular}{|c|c|c|c|}
\hline Code & Genotype & Source & Descriptive traits \\
\hline 146 & TAM146 & TAMUZ & $\begin{array}{l}\text { Open-pollinated, reticulatus group, medium fruit size, round/ oval, uniform, } \\
\text { dense and high netting, dark-orange flesh, good firmness, medium maturity, } \\
\text { and compact seed cavity }\end{array}$ \\
\hline $\mathrm{OC}$ & TAMOC & TAMU & $\begin{array}{l}\text { Open-pollinated, inodorus group/orange casaba, large fruit size, fruit shape oval, } \\
\text { creamy-white smooth skin, yellow flesh, high firmness, late maturity, and large } \\
\text { and loose seed cavity }\end{array}$ \\
\hline F39 & TAMF39 & TAMU & $\begin{array}{l}\text { Open-pollinated, reticulatus group, medium fruit size, round/oval, uniform, dense and high } \\
\text { netting, dark-orange flesh, good firmness, medium maturity, and compact seed cavity }\end{array}$ \\
\hline 1405 & TAM1405 & TAMU & $\begin{array}{l}\text { Open-pollinated, reticulatus group, medium-to-large fruit size, round/oval, uniform, dense } \\
\text { and high netting, dark-orange flesh, high firmness, late maturity. and compact seed cavity }\end{array}$ \\
\hline Ogdw & Orange Dew & $\begin{array}{l}\text { Shamrock Seed } \\
\text { Company, Inc. }\end{array}$ & $\begin{array}{l}\text { Open-pollinated, inodorus group, large fruit size, oval/round, creamy-white smooth } \\
\text { skin, salmon-orange flesh, high firmness, and late maturity }\end{array}$ \\
\hline MSN & Mission & $\begin{array}{l}\text { Seminis Vegetable } \\
\text { Seeds, Inc. }\end{array}$ & $\begin{array}{l}\text { F1 hybrid, reticulatus group, medium fruit size, round/oval, uniform and medium high } \\
\text { netting, dark-orange flesh, medium maturity, high sugar content, and small seed cavity }\end{array}$ \\
\hline Ord & Oro Duro & Sakata Seed America & $\begin{array}{l}\text { F1 hybrid, reticulatus group, medium size, round, good netting, yellow flesh, good firmness, } \\
\text { mid-maturity, and seed cavity closed }\end{array}$ \\
\hline Slr & Sol Real & Syngenta International AG & $\begin{array}{l}\text { F1 hybrid, reticulatus group, round, good netting, yellow flesh, good firmness, early maturity, } \\
\text { and tight seed cavity }\end{array}$ \\
\hline Jrny & Journey & Sakata Seed America & $\begin{array}{l}\text { F1 hybrid, reticulatus group, large size, oval, average netting, yellow flesh, medium firmness, } \\
\text { early maturity, and loose seed cavity }\end{array}$ \\
\hline
\end{tabular}


Co. Ltd., Tokyo, Japan) (Leskovar et al., 2006; Sharma et al., 2014).

A 100-g sample of edible mesocarp tissue was collected from the same fruits used for the above measurements; and the samples were stored at $-80{ }^{\circ} \mathrm{C}$ until a later date, when vitamin $C$ and $\beta$-carotene analyses were carried out. $\beta$-carotene was measured using the procedure described by Sadler et al. (1990) with some modifications. Total ascorbic acid/ vitamin $\mathrm{C}$ (TA) was extracted from $10 \mathrm{~g}$ of frozen $\left(-80^{\circ} \mathrm{C}\right)$ tissue in $10 \mathrm{~mL}$ of $3 \mathrm{~g} / 100$ $\mathrm{mL}$ meta-phosphoric acid (Sigma, St. Louis, MO) and was determined by using a highperformance liquid chromatography (HPLC) analysis method using ultraviolet-vis at 254 nm, as described in Sharma et al. (2014) and Wimalasiri and Wills (1983).

\section{Statistical analyses}

Analysis of variance (ANOVA) was performed using a generalized linear model procedure (SAS 9.2 version, SAS Inst., Cary, $\mathrm{NC}$ ) to test the significance of $\mathrm{G} \times \mathrm{E}$ interactions. Year-by-location interactions were considered as environments (i.e., nine) and analysis was performed as described by McIntosh (1983). The percentages of G, E, and $\mathrm{G} \times \mathrm{E}$ sum of squares of the total variation of three sources $[\mathrm{E}+\mathrm{G}+(\mathrm{G} \times \mathrm{E})]$ have been used to indicate the magnitude of variation contributed by each component (Dia et al., 2016a; Yan, 2001). When the data did not conform to model assumptions, the Box-Cox procedure was used to determine appropriate transformation to establish an acceptable level of homogeneity of variance across main factors. Treatment differences were determined using Duncan's multiple range test.

\section{Biplot analysis and its interpretation}

The parameters that had significant $\mathrm{G}$ or $\mathrm{G} \times$ $E$ interaction effects were analyzed with the stability analysis software known as GGE Biplot (Yan, 2001). Stability and mean performance of commercial and elite TAMU breeding lines were determined. The environmentcentered model $\left(Y_{i j}-\mu-\beta_{j}=\alpha_{i}+\Phi_{i j}\right)$ was used to construct GGE Biplots, where the $\mathrm{E}$ main effect $\left(\beta_{\mathrm{j}}\right)$ is removed, and the biplot contains only $\mathrm{G}\left(\alpha_{\mathrm{i}}\right)$ and $\mathrm{GE}\left(\Phi_{\mathrm{ij}}\right)$, which are the two sources of variation that are most relevant for $\mathrm{G} \times \mathrm{E}$ evaluations. The two-way genotype-by-environment data matrix was decomposed to principle components (PC) through singular value decomposition. The singular values of $\mathrm{PC} 1$ and $\mathrm{PC} 2$ were further divided into genotype and environment eigenvectors to construct meaningful biplots. Thus, GGE Biplot graphically presents the multienvironment data in two dimensions through principal components $\mathrm{PC} 1$ and PC2, which are unit-less measures and are depicted on the $x$ - and $y$-axis of a biplot, respectively. The percentage of total variation explained by $\mathrm{PC} 1$ and $\mathrm{PC} 2$ is presented on the biplot, which indicates its validity of approximation of $\mathrm{G}$ and $\mathrm{G} \times \mathrm{E}$ components for the trait investigated.

GGE Biplot is a versatile software that can generate different views of biplots. The average environment coordination view is used for ranking the genotypes based on mean performance and stability (e.g., Fig. 1A). This graph has two lines, the average environment axis (AEA) or average environment coordination (AEC) abscissa, and the AEC ordinate. AEA (in red) is the single arrowed line, which passes through the origin of the biplot and through the hypothetical average environment, denoted by the circle near W11. The direction of the arrowhead on the AEA points to higher mean values for the measured trait; in this case, total fruit yield (TFY). Thus TAMU 1405 and Journey had the lowest and highest TFY, respectively. The second line, the AEC ordinate (in blue), also called the stability line, has arrowheads at both ends. This line also passes through the origin of the biplot and goes perpendicular to

Table 2. Cumulative rainfall, average relative humidity (RH), mean maximum and minimum temperature, planting date and crop duration at College Station, Uvalde, and Weslaco, TX across the respective seasons, 2010, 2011, and 2012.

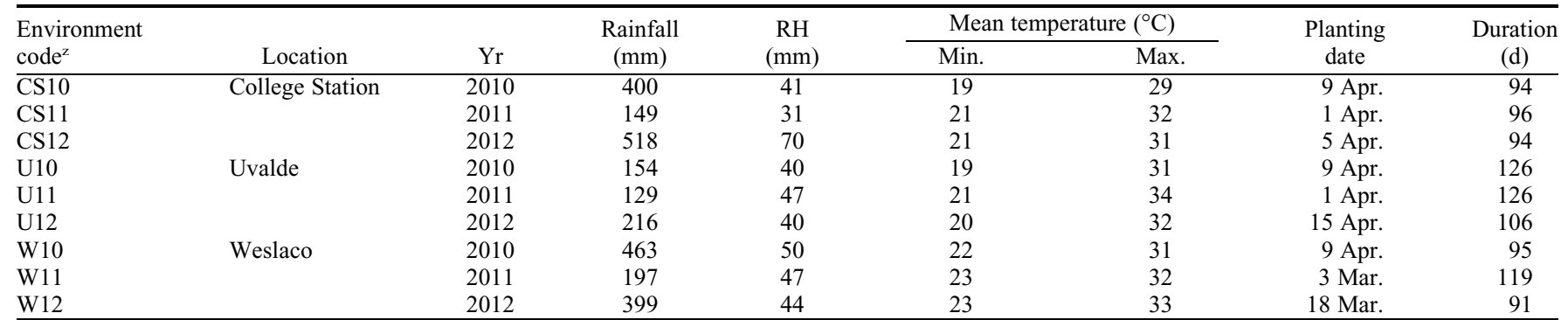

${ }^{\mathrm{z}}$ Environment code: $\mathrm{CS}=$ College Station, $\mathrm{U}=$ Uvalde, and $\mathrm{W}=$ Weslaco; and the code suffixes 10, 11, and 12 stand for 2010, 2011 , and 2012.
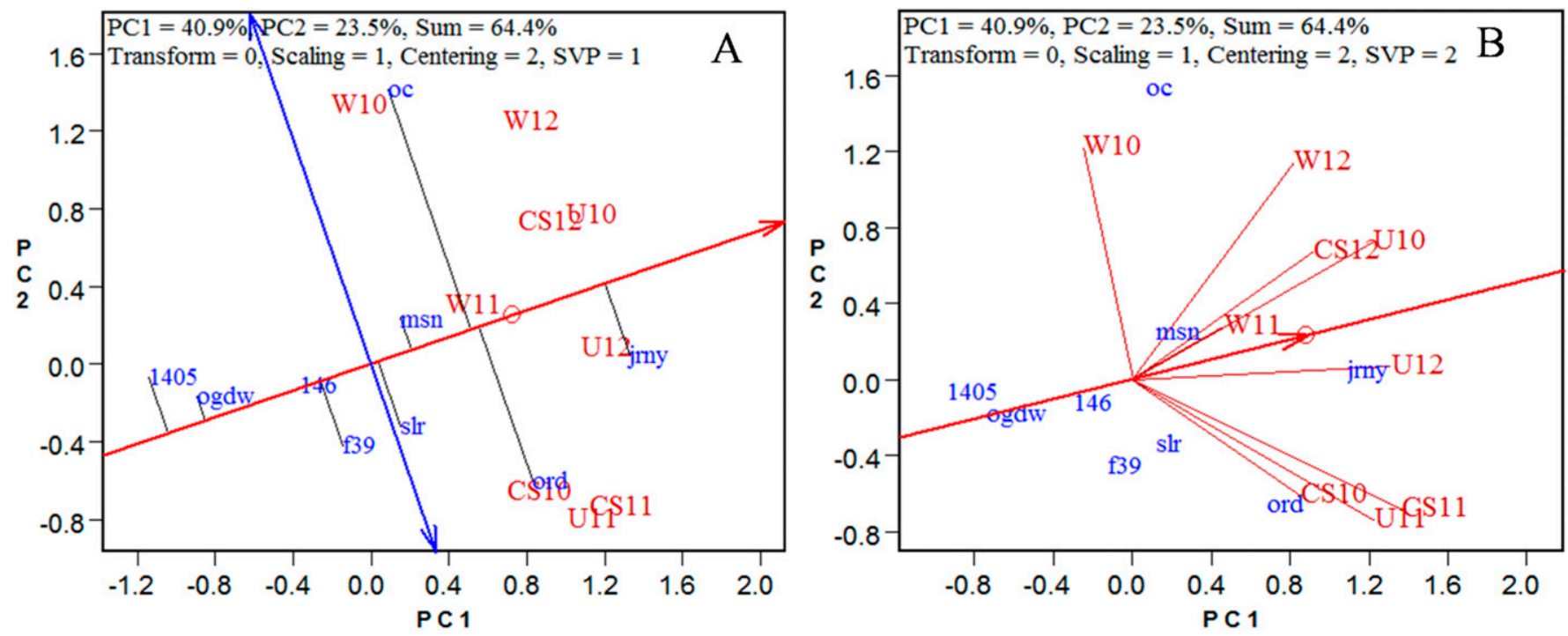

Fig. 1. Average coordination view of biplot (A), and discrimination and representativeness view of biplot (B) for total fruit yield. Genotype and environment codes are mentioned in Table 1. 
the AEA. The arrows on both the ends of AEC ordinate point to the higher instability (or greater variability) in either direction. Thus the shorter the projection or distance from AEA, the more stable or less variable the performance of the genotype among tested environments, and vice versa, i.e., TAMU 146 and TAMU OC are the most stable and unstable genotypes for TFY, respectively (Yan and Tinker, 2006). The environments are represented in uppercase italic letters (codes are as described in Table 2), and the genotypes are written in lowercase letters (codes are as described in Table 2).

The polygon view of the biplot presents which genotypes performed the best in one or more environments (e.g., Fig. 2D). The bestperforming genotypes in specific environments are described as winning genotypes. The lines originating from the center of the biplot and perpendicular to the sides of the polygon divide the plot into different sectors. The winning genotypes for each sector are the ones located on the vertex of the polygon, e.g., TAMU OC was the winning genotype in W10 and W12 environments. Figure 3 depicts the discriminative and representative ability of the GGE Biplot. The environment having a smaller angle with the AEA is more representative of other test environments. Higher vector length, which is proportional to the standard deviation within the respective environment, indicates greater discriminating ability of the environment. Thus, environments with representativeness and discriminating ability are good for selecting generally adapted genotypes; while the environment with discriminating ability, but not representativeness, is good for selecting specifically adapted genotypes (Yan and Tinker, 2006). For example, U10 is the representative environment for TFY.

\section{Results}

\section{Analysis of variance of $G, E$, and $G \times E$ components}

Tables 3 and 4 depict the ANOVA, $t$ test ( $P$ values), and the relative magnitudes of $\mathrm{G}$,
$\mathrm{E}$, and $\mathrm{G} \times \mathrm{E}$ variance components for nine traits. Table 4 consists of four yield traits and its component traits that show G, E, Y, and $\mathrm{L}$ components of variance and their interactions, while Table 4 involves five fruit-quality traits. Irrespective of trait, the genotypic $(G)$ contribution to total variation ranged from $5 \%$ to $58 \%$, the $\mathrm{E}$ ranged from $20 \%$ to $83 \%$, and $\mathrm{G} \times \mathrm{E}$ ranged from $8 \%$ to $48 \%$ (Tables 3 and 4). Overall, the E contributed more than $70 \%$ of the total variation for yield and $\mathrm{FN}$; while in $\mathrm{FW}$, the E contribution was $24 \%$. The contribution of $\mathrm{G}$ to the total sum of squares was relatively small in TFY $(5 \%)$, MFY ( $9 \%)$, and FN (9\%; Table 4). The higher percentage of total variation attributed to $\mathrm{G}$ for $\mathrm{FW}$ (58\%), as compared with $\mathrm{FN}$ $(9 \%)$, suggested that G was relatively more important in FW than FN. Furthermore, $\mathrm{G} \times$ E contribution was also higher in FW (18\%) than FN (8\%), which indicates that FW was more responsible for fluctuations in TFY and MFY across environments than FN.

In fruit-quality traits, $\mathrm{E}$ contributed less than $70 \%$ of the total variation, except for
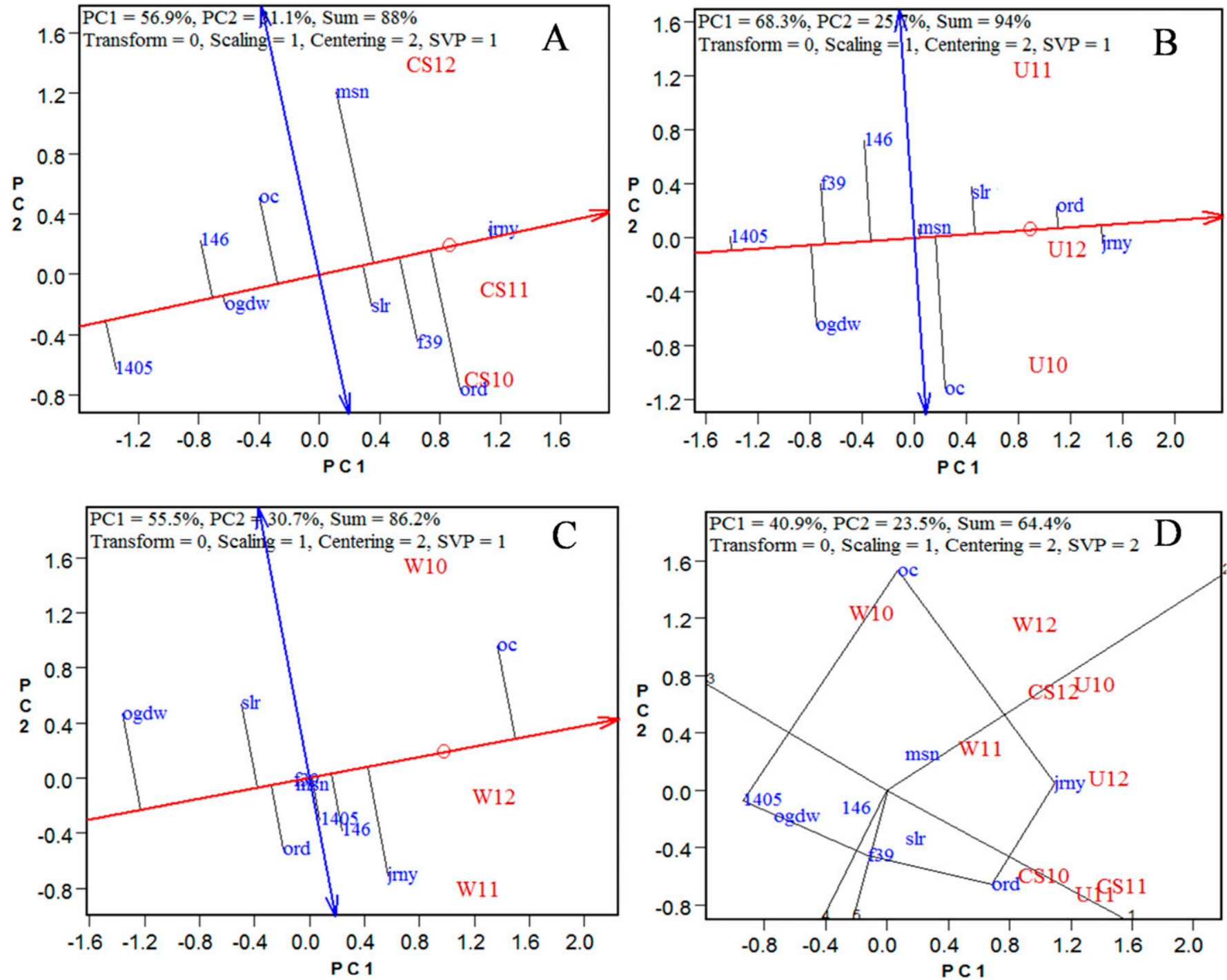

Fig. 2. Average coordination view of biplot for College Station (A), Uvalde (B), and Weslaco (C); and polygon view (D) of biplot for total fruit yield. Genotype and environment codes are mentioned in Table 1. 

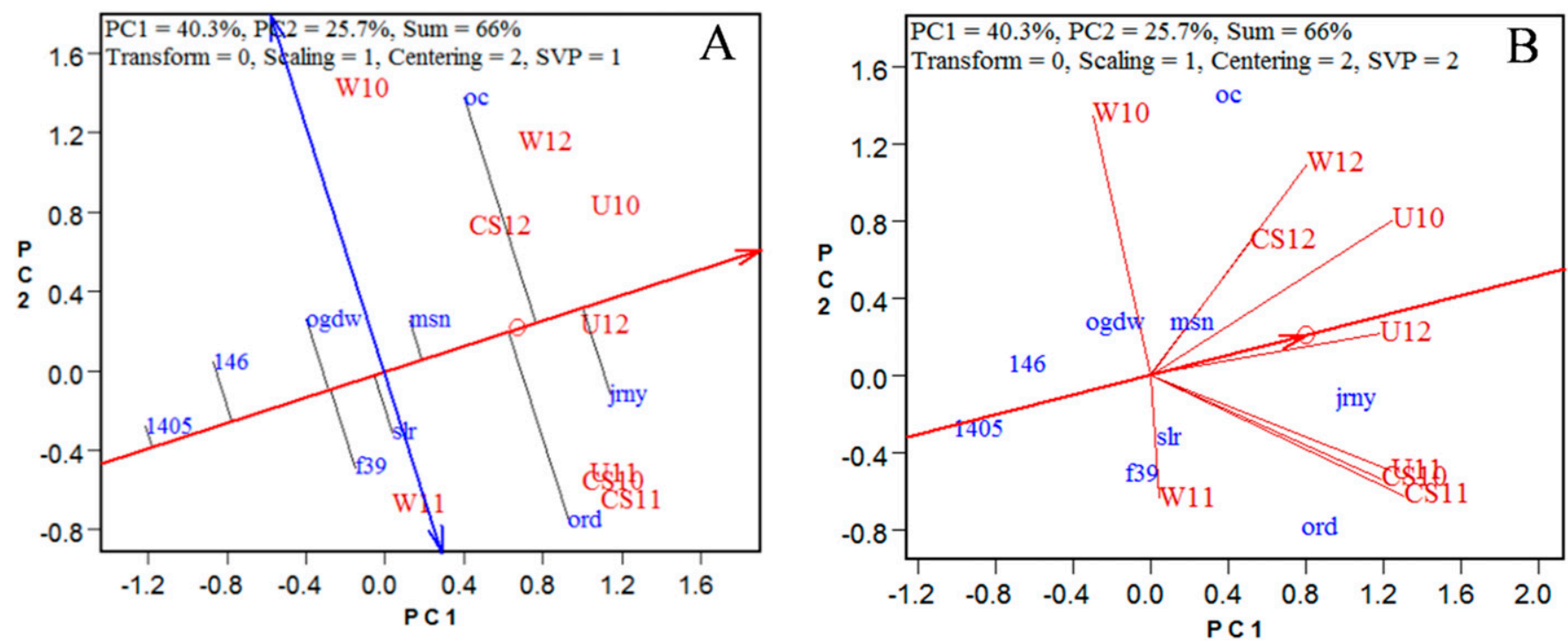

Fig. 3. Average coordination view of biplot (A), and discrimination and representativeness view of biplot (B) for marketable fruit yield. Genotype and environment codes are mentioned in Table 1.

Table 3. Preplant soil physical and chemical properties of experimental site in 2010, 2011, and 2012 seasons at College Station, Uvalde, and Weslaco, TX.

\begin{tabular}{|c|c|c|c|c|c|c|c|c|c|c|c|c|c|c|c|}
\hline \multirow[b]{2}{*}{ Location } & \multirow[b]{2}{*}{ Yr } & \multirow[b]{2}{*}{ Soil texture } & Sand & Silt & Clay & Organic Matter & \multirow{2}{*}{\multicolumn{2}{|c|}{$\begin{array}{cc} & \text { Conductivity } \\
\mathrm{pH} & \left(\mu \mathrm{mhos} \cdot \mathrm{cm}^{-1}\right)\end{array}$}} & $\mathrm{NO}_{3}-\mathrm{N}$ & $\mathrm{P}$ & $\mathrm{K}$ & $\mathrm{Ca}$ & $\mathrm{Mg}$ & $\mathrm{S}$ & $\mathrm{Na}$ \\
\hline & & & \multicolumn{4}{|c|}{------------------------о\%---------------------- } & & & \multicolumn{7}{|c|}{--------------------mg.kg-1------------------ } \\
\hline & 2010 & Sandy loam & 71 & 24 & 5 & 5.74 & 6.7 & 291 & 34 & 294 & 277 & 2,527 & 315 & 25 & 98 \\
\hline & 2012 & Sandy loam & 72 & 18 & 10 & 3.64 & 7.7 & 272 & 44 & 256 & 228 & 3,255 & 273 & 23 & 367 \\
\hline Uvalue & 2010 & Loam & 33 & 40 & 27 & 2.66 & 7.8 & 58 & 60 & 64 & 737 & 13,101 & 302 & 20 & 94 \\
\hline & 2011 & Clay & 31 & 27 & 42 & 2.60 & 7.7 & 324 & 10 & 73 & 714 & 13,432 & 332 & 23 & 106 \\
\hline & 2011 & Sandy clay loam & 59 & 18 & 23 & 0.93 & 7.7 & 503 & 42 & 51 & 57 & 4,219 & 321 & 33 & 106 \\
\hline & 2012 & Sandy clay loam & 68 & 14 & 18 & 0.80 & 8.0 & 230 & 19 & 82 & 490 & 3,250 & 323 & 17 & 143 \\
\hline
\end{tabular}

Soil samples (0- to $15-\mathrm{cm}$ depth) were collected before planting for the respective seasons.

Table 4. ANOVA of total fruit yield (TFY), marketable fruit yield (MFY), fruit number per plant (FN), average fruit weight (FW), fruit firmness (N), soluble solids content (SSC), $\beta$-carotene, and vitamin $\mathrm{C}$ as influenced by genotype $(\mathrm{G})$, environment $(\mathrm{E})$, and genotype $\times$ environment $(\mathrm{G} \times \mathrm{E})$; and percent contribution of $\mathrm{G}$, $\mathrm{E}$, and $\mathrm{G} \times \mathrm{E}$ to total variation (i.e., $\mathrm{G}+\mathrm{E}+\mathrm{G} \times \mathrm{E}$ ) of yield and components in melons.

\begin{tabular}{|c|c|c|c|c|c|c|c|c|c|c|c|c|c|c|c|c|c|}
\hline \multirow[b]{2}{*}{ Source } & \multirow[b]{2}{*}{$\mathrm{df}$} & \multicolumn{2}{|c|}{ TFY } & \multicolumn{2}{|c|}{ MFY } & \multicolumn{2}{|c|}{ FN } & \multicolumn{2}{|c|}{ FY } & \multicolumn{2}{|c|}{ Firmness } & \multicolumn{2}{|c|}{ SSC } & \multicolumn{2}{|c|}{$\beta$-carotene } & \multicolumn{2}{|c|}{ Vitamin C } \\
\hline & & $P$ value & $\begin{array}{c}\% \text { of } \\
\text { TV }\end{array}$ & $P$ value & $\begin{array}{c}\% \text { of } \\
\text { TV }\end{array}$ & $P$ value & $\begin{array}{c}\text { \% of } \\
\text { TV }\end{array}$ & $P$ value & $\begin{array}{c}\% \text { of } \\
\text { TV }\end{array}$ & $P$ value & $\begin{array}{c}\text { \% of } \\
\text { TV }\end{array}$ & $P$ value & $\begin{array}{l}\% \text { of } \\
\text { TV }\end{array}$ & $P$ value & $\begin{array}{c}\% \text { of } \\
\text { TV }\end{array}$ & $P$ value & $\begin{array}{c}\% \text { of } \\
\text { TV }\end{array}$ \\
\hline $\mathrm{E}$ & 8 & $<0.0001$ & 83 & $<0.0001$ & 70 & $<0.0001$ & 83 & $<0.0001$ & 24 & $<0.0001$ & 54 & $<0.0001$ & 65 & $<0.0001$ & 19 & $<0.0001$ & 72 \\
\hline $\mathrm{Y} \times \mathrm{L}$ & 4 & $<0.0001$ & 7 & $<0.0001$ & 7 & $<0.0001$ & 6 & $<0.0001$ & 6 & $<0.0001$ & 21 & $<0.0001$ & 12 & $<0.0001$ & 9 & $<0.0001$ & 17 \\
\hline G & 8 & $<0.0001$ & 5 & $<0.0001$ & 9 & $<0.0001$ & 9 & $<0.0001$ & 58 & $<0.0001$ & 19 & $<0.0001$ & 17 & $<0.0001$ & 54 & $<0.0001$ & 18 \\
\hline $\mathrm{G} \times \mathrm{E}$ & 64 & 0.0055 & 11 & $<0.0001$ & 21 & 0.0008 & 8 & $<0.0001$ & 18 & 0.2877 & 27 & $<0.0001$ & 18 & $<0.0001$ & 27 & 0.0216 & 11 \\
\hline $\mathrm{G} \times \mathrm{Y} \times \mathrm{L}$ & 32 & 0.5564 & 3 & 0.0077 & 9 & 0.6548 & 2 & $<0.0001$ & 9 & 0.0003 & 15 & 0.021 & 6 & $<0.0001$ & 15 & 0.2083 & 6 \\
\hline
\end{tabular}

$\mathrm{TV}=$ total variation; $\mathrm{Y}=$ years; $\mathrm{L}=$ location.

vitamin $\mathrm{C}$, where the $\mathrm{E}$ contribution was $73 \%$ (Table 4). In general, the $\mathrm{G}$ contribution to the total variation was higher for quality traits as compared with yield traits with the highest in $\beta$-carotene $(54 \%)$, suggesting that $G$ was relatively more important in $\beta$-carotene as compared with vitamin $\mathrm{C}$, where $\mathrm{G}$ contributed only $16 \%$ to the total variation. Furthermore, $\mathrm{G} \times \mathrm{E}$ contribution was higher in dehydroascorbic acid (48\%) compared with other quality traits (data not shown), which led to the differential response of melon genotypes across environments for vitamin C.

Overall, TFY, MFY, FN, firmness, $\beta$-carotene and vitamin $\mathrm{C}$ content was higher in 2012 than in 2010 and 2011, while the highest FW and the lowest SSC were recorded in 2010. Among locations, the highest values for TFY, MFY, FN, firmness, and vitamin C content were recorded at Uvalde, while the highest $\mathrm{FW}$ and $\mathrm{SSC}$ were recorded at
Weslaco and College Station, respectively (Table 5).

For the traits in which $\mathrm{G} \times \mathrm{E}$ contributed significantly to the total variation, the genotypes responded differently to a stimulus (i.e., a change across environments that influences the phenotypic expression of those traits, for example soil type) in the tested environments. Thus, the specifically betterperforming genotypes in a particular environment and/or most suitable environments 
Table 5. Mean total fruit yield (TFY), marketable fruit yield (MFY), fruit number per plant (FN), average fruit weight (FW), fruit firmness (N), soluble solids content (SSC), $\beta$-carotene, and vitamin $\mathrm{C}$ as influenced by year, location, and genotype.

\begin{tabular}{|c|c|c|c|c|c|c|c|c|}
\hline Source & $\begin{array}{c}\text { TFY } \\
\left(\mathrm{t} \cdot \mathrm{ha}^{-1}\right)\end{array}$ & $\begin{array}{c}\text { MFY } \\
\left(\mathrm{t} \cdot \mathrm{ha}^{-1}\right)\end{array}$ & $\begin{array}{l}\mathrm{FN} \\
\text { (no.) }\end{array}$ & $\begin{array}{l}\mathrm{FW} \\
(\mathrm{kg})\end{array}$ & $\begin{array}{c}\text { Firmness } \\
(\mathrm{N})\end{array}$ & $\begin{array}{l}\mathrm{SSC} \\
(\%)\end{array}$ & $\begin{array}{c}\beta \text {-carotene } \\
\left(\mu \mathrm{g} \cdot \mathrm{g}^{-1} \mathrm{FW}\right)\end{array}$ & $\begin{array}{l}\text { Vitamin C } \\
\left(\mu \mathrm{g} \cdot \mathrm{g}^{-1} \mathrm{FW}\right)\end{array}$ \\
\hline \multicolumn{9}{|l|}{ Year } \\
\hline 2010 & $49.6 b^{z}$ & $32.5 \mathrm{c}$ & $1.6 \mathrm{c}$ & $4.0 \mathrm{a}$ & $24.6 \mathrm{c}$ & $8.4 \mathrm{~b}$ & $19.9 \mathrm{~b}$ & $185.8 \mathrm{c}$ \\
\hline 2011 & $53.3 \mathrm{~b}$ & $37.2 \mathrm{~b}$ & $2.1 \mathrm{~b}$ & $3.1 \mathrm{~b}$ & $27.0 \mathrm{~b}$ & $10.2 \mathrm{a}$ & $21.1 \mathrm{~b}$ & $230.7 \mathrm{~b}$ \\
\hline 2012 & $62.7 \mathrm{a}$ & $46.1 \mathrm{a}$ & $2.4 \mathrm{a}$ & $3.7 \mathrm{a}$ & $31.6 \mathrm{a}$ & $10.4 \mathrm{a}$ & $23.6 \mathrm{a}$ & $287.8 \mathrm{a}$ \\
\hline \multicolumn{9}{|l|}{ Location } \\
\hline College Station & $31.4 \mathrm{c}$ & $24.7 \mathrm{c}$ & $1.0 \mathrm{c}$ & $2.6 \mathrm{c}$ & $24.4 \mathrm{c}$ & $9.6 \mathrm{~b}$ & $23.4 \mathrm{a}$ & $235.3 \mathrm{~b}$ \\
\hline Uvalde & $88.4 \mathrm{a}$ & $60.1 \mathrm{a}$ & $3.5 \mathrm{a}$ & $4.0 \mathrm{~b}$ & $31.6 \mathrm{a}$ & $10.9 \mathrm{a}$ & $20.8 \mathrm{~b}$ & $304.0 \mathrm{a}$ \\
\hline Weslaco & $52.4 \mathrm{~b}$ & $34.0 \mathrm{~b}$ & $1.8 \mathrm{~b}$ & $4.3 \mathrm{a}$ & $27.1 \mathrm{~b}$ & $8.6 \mathrm{c}$ & $21.3 \mathrm{~b}$ & $177.0 \mathrm{c}$ \\
\hline \multicolumn{9}{|l|}{ Genotype } \\
\hline TAM146 & $51.1 \mathrm{~cd}$ & $29.7 \mathrm{~d}$ & $2.0 \mathrm{bc}$ & $1.5 \mathrm{~d}$ & $28.8 \mathrm{bc}$ & $8.6 \mathrm{~d}$ & $25.1 \mathrm{a}$ & $175.4 \mathrm{e}$ \\
\hline TAMOC & $62.0 \mathrm{ab}$ & $46.6 \mathrm{ab}$ & $1.3 \mathrm{e}$ & $2.8 \mathrm{a}$ & $30.7 \mathrm{ab}$ & $10.1 \mathrm{~b}$ & $11.3 \mathrm{e}$ & $168.6 \mathrm{e}$ \\
\hline TAMF39 & $54.7 \mathrm{bc}$ & $36.4 \mathrm{c}$ & $2.0 \mathrm{c}$ & $1.7 \mathrm{c}$ & $25.0 \mathrm{~cd}$ & $8.7 \mathrm{~d}$ & $21.4 \mathrm{c}$ & $260.3 \mathrm{bc}$ \\
\hline TAM1405 & $44.9 \mathrm{~d}$ & $29.9 \mathrm{~d}$ & $1.7 \mathrm{~d}$ & $1.8 \mathrm{c}$ & $28.7 \mathrm{bc}$ & $9.1 \mathrm{~cd}$ & $22.2 \mathrm{c}$ & $242.6 \mathrm{dc}$ \\
\hline Orange Dew & $45.9 \mathrm{~d}$ & $37.0 \mathrm{c}$ & $1.6 \mathrm{~d}$ & $1.7 \mathrm{c}$ & $33.6 \mathrm{a}$ & $11.3 \mathrm{a}$ & $19.1 \mathrm{~d}$ & $235.4 \mathrm{~cd}$ \\
\hline Mission & $56.7 \mathrm{bc}$ & $40.9 \mathrm{a}-\mathrm{c}$ & $2.4 \mathrm{a}$ & $1.5 \mathrm{~d}$ & $28.8 \mathrm{bc}$ & $9.9 \mathrm{~b}$ & $24.0 \mathrm{ab}$ & $287.9 \mathrm{a}$ \\
\hline Oro Duro & $59.4 \mathrm{a}-\mathrm{c}$ & $38.7 \mathrm{c}$ & $2.5 \mathrm{a}$ & $1.5 \mathrm{~d}$ & $21.8 \mathrm{~d}$ & $9.7 \mathrm{bc}$ & $25.5 \mathrm{a}$ & $277.7 \mathrm{ab}$ \\
\hline Sol Real & $56.6 \mathrm{bc}$ & $39.9 \mathrm{bc}$ & $2.3 \mathrm{ab}$ & $1.6 \mathrm{~cd}$ & $26.2 \mathrm{c}$ & $9.8 \mathrm{~b}$ & $22.4 \mathrm{bc}$ & $259.3 \mathrm{bc}$ \\
\hline Journey & $65.7 \mathrm{a}$ & $47.2 \mathrm{a}$ & $1.9 \mathrm{c}$ & $2.3 \mathrm{~b}$ & $26.8 \mathrm{bc}$ & $9.5 \mathrm{bc}$ & $21.8 \mathrm{c}$ & $231.0 \mathrm{~d}$ \\
\hline
\end{tabular}

${ }^{\mathrm{z}}$ Means in a column have been separated by Duncan's multiple range test at $P \leq 0.05$.

$\mathrm{FW}=$ fresh weight.

can be identified and exploited for the traits of interest. All variables were significant $(P \leq$ 0.05 ) for either $\mathrm{G}$ and/or $\mathrm{G} \times \mathrm{E}$ (Table 4$)$, indicating that the analysis in GGE Biplot was appropriate for these traits (Yan and Tinker, 2006).

\section{Total fruit yield}

The mean TFY of all genotypes ranged from 48.0 (TAM 1405) to $69.4 \mathrm{t} \cdot \mathrm{ha}^{-1}$ (Journey), and the grand mean TFY was $54.8 \mathrm{t} \cdot \mathrm{ha}^{-1}$. Figure $1 \mathrm{~A}$ indicates that TAMU breeding line 146 was most stable for TFY, but it had a lower mean TFY than that of the grand mean. Mission had higher TFY than the grand mean and moderate stability. In contrast, the longest vector length of TAMU OC from the average environment axis (AEA) indicates this genotype as having the lowest stability for TFY, thus contributing to large $\mathrm{G} \times \mathrm{E}$ interactions.

Discriminative and representative views of the GGE Biplot showed that U10 and U12 were the most representative environments for TFY. Moreover, U10, U11, and U12 showed good discriminative ability among genotypes for TFY. Thus, overall the Uvalde location is a good for selecting generally adapted genotypes for south-central Texas (Fig. 1B).

The biplot analysis for the different locations indicated a change in ranking of genotypes based on mean performance and stability for TFY, with TAMU OC having the highest mean TFY at Weslaco; while Journey produced the highest TFY at College Station and Uvalde (Fig. 2A-C). Furthermore, the significant $\mathrm{G} \times \mathrm{L}$ interactions $(P=0.008)$ justified the use of a site regression (SREG) model for analysis of TFY (Table 4). The polygon view of the biplot indicated that TAMU OC was specifically adapted to W10 and W12 environments; however, W11 also occurred close to the sector line (Fig. 2D). These results suggested that TAMU OC was specifically adapted to Weslaco. Similarly, Journey performed best at U12 and U10, and Oro Duro in CS10 and CS11. This result indicates that Journey and Oro Duro were specifically suited for cultivation in Uvalde and College Station, respectively. The performance varied among years, indicating nonrepeatable $\mathrm{G} \times \mathrm{E}$ interactions. Except for TAMU $\mathrm{OC}$, open pollinated genotypes produced less TFY than the grand mean.

\section{Marketable fruit yield}

Like TFY, the mean MFY ranged from 31.5 (TAMU 1405) to $49.8 \mathrm{t} \cdot \mathrm{ha}^{-1}$ (Journey), with a grand mean of $38.4 \mathrm{t} \cdot \mathrm{ha}^{-1}$. Biplot analysis for MFY indicated that the trend in mean performance and stability rankings were like TFY, with Journey ranking the highest, followed by TAMU OC and Oro Duro (Fig. 3A). Mission was the second most stable genotype after TAMU 1405 for MFY, with a mean MFY (42.7 th.ha $\left.{ }^{-1}\right)$ higher than the grand mean. Contrary to the TFY, TAMU 146 ranked lower than Orange Dew for mean MFY and stability. TAMU breeding lines TAMU 1405 and TAMU 146 had the lowest mean MFY, whereas TAMU F39 ranked equivalent to Orange Dew and 2\% (38.4 vs. $\left.37.7 \mathrm{t} \cdot \mathrm{ha}^{-1}\right)$, lower than the grand mean.

Like TFY, TAMU OC performed better in W10 and W12, Journey in U12, and Oro Duro in CS10 and CS11 environments, which indicated that TAMU OC, Journey, and Oro Duro were specifically suited for cultivation in Weslaco, Uvalde, and College Station, respectively.

Discriminative and representative views of the GGE Biplot showed that U10, U11, and U12 were the most representative environments. Moreover, these environments showed good discriminative ability among genotypes for MFY. Thus overall, the Uvalde location can be an ideal environment for selecting generally adapted genotypes for MFY in south-central Texas (Fig. 3B).

\section{Fruit number and fruit weight}

Because the $\mathrm{G}$ component contributed $58 \%$ of the total variation for $\mathrm{FW}$, there was no apparent specific adaption to a particular environment observed (Fig. 4A). Based on mean and stability, TAMU OC ranked the highest for mean FW followed by Journey. Oro Duro, followed by Mission, were the most stable genotypes; while TAMU OC was most variable for fruit weight. The mean FN ranged from 1.5 (TAMU OC) to 2.8 (Oro Duro) fruits per plant, with a grand mean of 1.96 fruits per plant. The average coordinate view of the GGE Biplot for FN indicated that the genotype Mission ranked second for mean FN with moderate stability, followed by Sol Real. Breeding lines TAMU F39 and 146 had above-average FN values.

\section{Fruit firmness}

The mean fruit firmness of all genotypes ranged from 21.5 (Oro Duro) to $33.2 \mathrm{~N}$ (Orange Dew), with grand mean of $27.9 \mathrm{~N}$. The average coordinates view of the GGE Biplot for firmness indicated that genotype Orange Dew ranked highest for mean fruit firmness and stability, followed by TAMU OC for highest mean firmness. However, this was the most unstable genotype (Fig. 5A). Mission ranked second for stability, having mean fruit firmness higher than the grand mean. Breeding lines TAMU 146 and 1405 had a mean firmness higher than Sol Real and Oro Duro, as well as the grand mean. The environments U10 and U12 had the shortest projections from AEA axis, while in 2011, U11 and CS11 markers had the same projection and distance from the biplot origin. These results indicated that overall, the Uvalde location was most representative, with similar discriminative ability for evaluating melon cultivars for firmness.

\section{Soluble solids content}

The mean SSC of all genotypes ranged from 8.7 (TAMU 146, TAMU F39) to 11.2 (Orange Dew), with grand mean of $9.7^{\circ}$ brix. The average coordinate view of the GGE Biplot indicated that the genotype Orange 

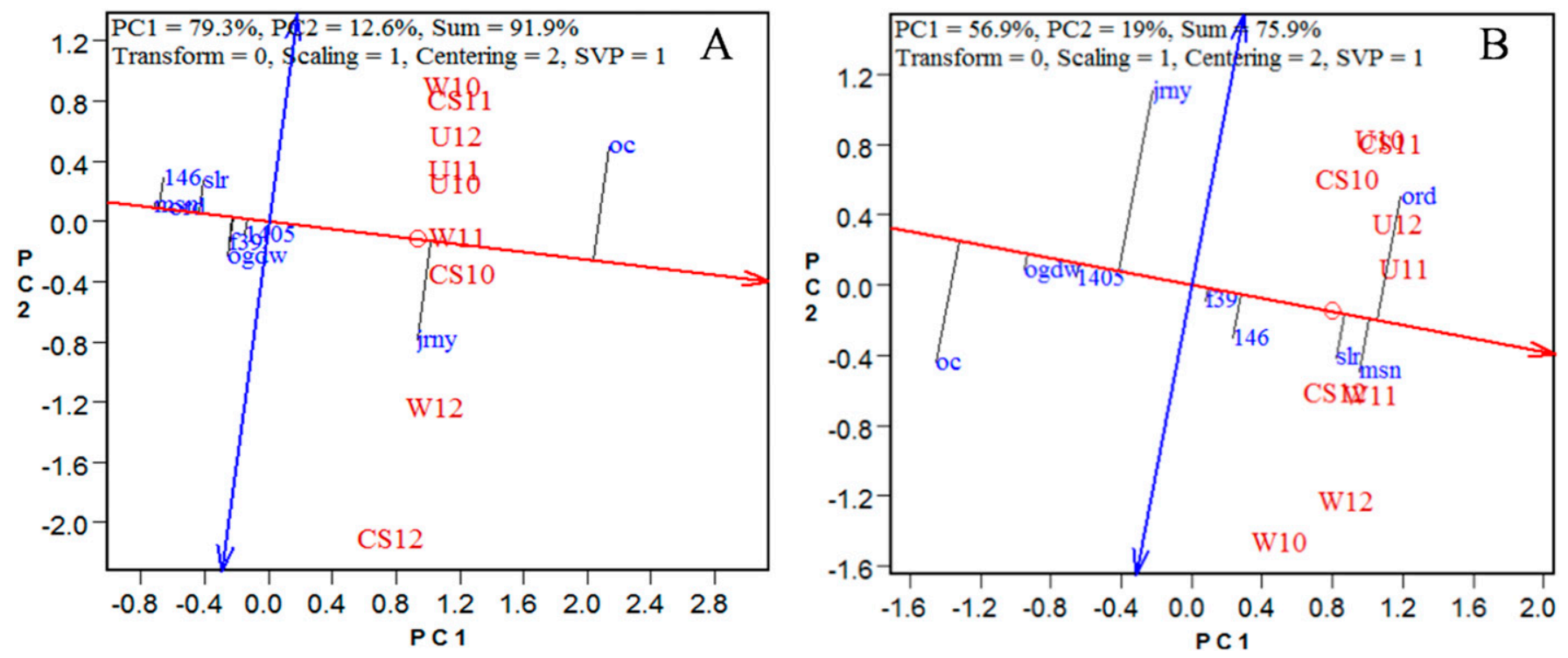

Fig. 4. Average coordination view of biplot for fruit weight $(\mathbf{A})$ and fruit number (B). Genotype and environment codes are mentioned in Table 1.

Dew ranked highest, followed by Mission, for mean SSC (Fig. 5B). The polygon view of the biplot indicated that TAMU OC had specific adaptation to $\mathrm{W} 11$; while Orange Dew had specific adaption to U10, U11, U12, and CS11 environments (Fig. 5C). These results suggested that TAMU OC was specifically adapted to the Weslaco location, while Orange Dew to the Uvalde location. Environment W10 had the shortest projection from AEA axis, while in 2011 and 2012, U11 and U12 markers had the shortest projection from AEA axis and longest distance from the biplot origin. These results indicated that overall, the Uvalde location was the most discriminative and representative for evaluating melon cultivars for SSC (Fig. 5D).

\section{$\beta$-carotene}

The genotypic $(\mathrm{G})$ component contributed $54 \%$ to the total variation, which was higher than the $\mathrm{G} \times \mathrm{E}$ component (Table 4). Oro Duro and TAMU 146 had the highest mean $\beta$-carotene content $\left(25.75 \mu \mathrm{g} \cdot \mathrm{g}^{-1}\right)$ of all genotypes. The genotype Mission had the highest stability, with a mean $\beta$-carotene content of $23.9 \mu \mathrm{g} \cdot \mathrm{g}^{-1}$, which was higher than the grand mean (Fig. 6A). The environment W11 had the shortest projection from AEA axis, while CS12 had the longest projection. These results indicated that overall, the Weslaco location was the most representative and discriminative environment for evaluating melon cultivars for $\beta$-carotene (Fig. 6A).

\section{Vitamin C}

Like $\beta$-carotene, the $\mathrm{G}$ contribution was higher than that of $\mathrm{G} \times \mathrm{E}(16 \%$ vs. $10 \%)$ to the total variation for vitamin $\mathrm{C}$ content (Table 4). The mean vitamin $\mathrm{C}$ of all genotypes ranged from 155.8 (TAMU OC) to $285.8 \mu \mathrm{g} \cdot \mathrm{g}^{-1}$ (Mission) (Fig. 6B). Journey and Orange Dew were the most stable and variable genotypes for vitamin $\mathrm{C}$ content, respectively. However, Mission had an aver- age stability, with the highest mean vitamin C content. TAMU 1405 and TAMU F39 had mean vitamin $\mathrm{C}$ contents higher than the grand mean. No systematic patterns were observed for locations or specific adaptability of melon genotypes for vitamin $\mathrm{C}$ content.

\section{Discussion}

Selection of genotypes for high mean yield performance and stability is critical for crop production in semiarid regions of the world. In these regions, the growing environments are usually unpredictable due to erratic rainfall distribution both in space and time, which causes genotypic responses to vary across environments (Cattivelli et al., 2008). This fact becomes more important in crops like melon, where acceptable marketable fruit quality (i.e., firmness, level of SSC and phytonutrients) is as important as fruit yield. In a $\mathrm{G} \times \mathrm{E}$ interaction study on muskmelons, Wolf et al. (1994) emphasized the need of multiple year and location evaluations for selecting stable and high-yielding cultivars.

\section{Fruit yield and its components}

Environmental and $\mathrm{G} \times \mathrm{E}$ can have significant effects on melon fruit yield (Dhakare and More, 2008; Kultur et al., 2001). Like the previous studies, the E component accounted for more than $70 \%$ of the total variation in MFY, TFY, and FN (Dhakare and More, 2008; Kang, 2002). In watermelon, Dia et al. (2016a) reported that E contribution to fruit size was $15 \%$ as compared with $48 \%$ to marketable fruit yield. Like in the current study, E contributed $24 \%$ in FW as compared with $83 \%$ in TFY (Table 3).

Except in FW, the genotypic contribution to the total variation in TFY, MFY, and FN was considerably lower than that of $\mathrm{E}$ (Table 4). However, G contributions to the total variation were highly significant for all fruit yield traits. The $\mathrm{G} /(\mathrm{G} \times \mathrm{E})$ ratio in $\mathrm{FW}$ was 3.2 as compared with 1.3 in FN, indicating the high heritability of FW in melons; thus FW was less influenced by the environment than FN. For fruit size in watermelon, G effect contributed $52 \%$ to the total variance (Dia et al. 2016a).

The $\mathrm{G} \times \mathrm{E}$ interactions ranged from $8 \%$ to $21 \%$ among the yield traits. The magnitude of $\mathrm{G} \times \mathrm{E}$ variance (as compared with $\mathrm{G}$ ) indicated that multienvironment cultivar evaluations are critical in muskmelon breeding programs (Dia et al., 2018). Furthermore, genotype $(\mathrm{G})$ by year $(\mathrm{Y})$ interactions were also highly significant for yield traits, suggesting that $\mathrm{G} \times \mathrm{Y}$ interactions are important to consider for developing stable cultivars adapted for a specific environment (Joshi et al., 2011). The genotype (G) by location (L) interactions were also significant for these traits, indicating the need of regionalization of melon breeding programs (Dia et al., 2016a, 2018). In a planting density study at two locations, Kultur et al. (2001) found that $\mathrm{G} \times \mathrm{L}$ interactions had significant effects on FN, FW, and TFY in melons. In watermelon, $\mathrm{G} \times \mathrm{L}$ and $\mathrm{G} \times \mathrm{Y} \times \mathrm{L}$ interactions had significant effect on marketable fruit yield (Dia et al., 2016a). Furthermore, Wolf et al. (1994) also reported significant $G \times Y \times$ $\mathrm{L}$ interactions for marketable fruit yield in melons, and they attributed these differential responses to climate fluctuations, planting date, and stress factors.

A genotype with mean performance and less variability in yielding ability across a set of test environments is considered a stable or ideal genotype for that mega-environment, for a particular trait (Joshi et al., 2011; Kang, 2002). Biplot analysis of TFY and MFY indicated that Mission was an ideal genotype; it had good stability along with average productivity greater than the grand mean. TAMU OC, Oro Duro, and Journey were the most variable genotypes across environments, 

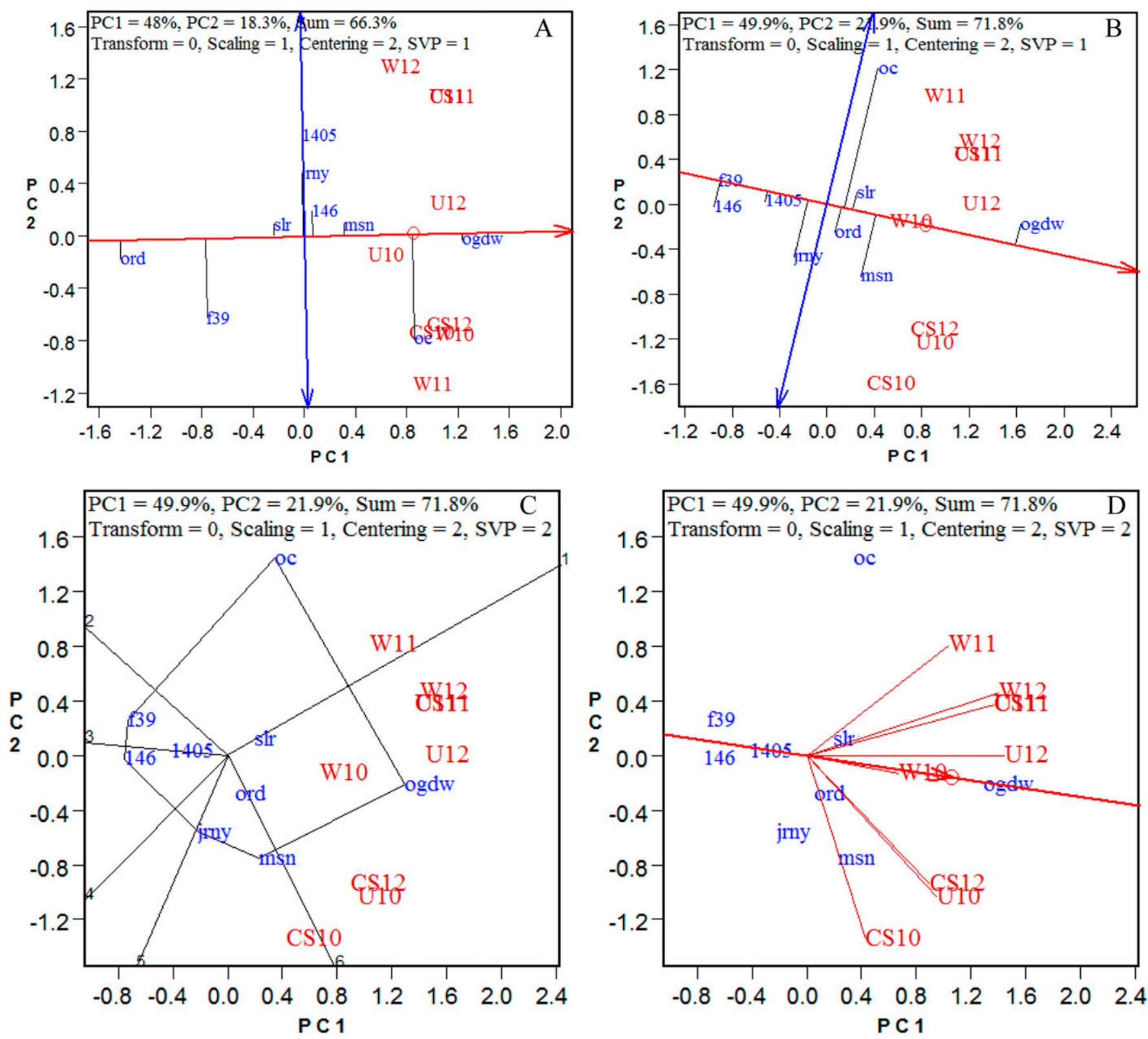

Fig. 5. Average coordination view of biplot for fruit firmness (A); and average coordination view (B), polygon view (C), and discrimination and representativeness view (D) of biplot for soluble solids content. Genotype and environment codes are mentioned in Table 1.

and these were specifically adapted to Weslaco, College Station and Uvalde locations, despite yearly fluctuations. TAMU F39 was more stable and better performing than Mission at College Station (Fig. 2A) and like Mission at Weslaco. Overall, TAMU F39 produced almost equivalent MFY to the grand mean. TAMU 146 was most consistent for TFY across environments, but it produced comparatively lower fruit yield than the grand mean (Fig. 1A); thus it possessed biological stability (Jamshidmoghaddam and Pourdad, 2012), which indicates this genotype is less responsive to environmental variation. The Uvalde location was found to be the most suitable for melon cultivar evaluations for fruit yield.

The impact of environment (E) was variable on fruit-quality traits, with $\mathrm{E}$ being $72 \%$ for vitamin $\mathrm{C}$ content; the lowest variance attributed to the E component was $19 \%$ for $\beta$-carotene (Table 4). Both years and locations had significant impacts on all the fruit quality traits. In 2012, all the fruit quality traits had maximum values, which can be attributed to the favorable weather experienced during the fruit development and maturity stage at the Uvalde location. Although the Uvalde location experienced drought during the years of study, in 2012 the rains received in the beginning of the crop season resulted in good crop establishment and growth (Table 2). The period corresponding to fruit maturity and ripening remained comparatively dry, a situation which is considered good for fruit quality enhancement in melons (data not shown). Among the locations, Uvalde had the highest firmness, SSC, and vitamin $\mathrm{C}$ content, while College station had the highest $\beta$-carotene. The highest firm- ness and vitamin $\mathrm{C}$ content at Uvalde can be attributed to the high calcium content of the soils and the clay loam texture (Table 3 ) of the soil (Lester and Crosby, 2002; Lester and Grusak, 2004).

The $\mathrm{G} \times \mathrm{L}$ interactions $(P=0.301)$ were not significant statistically, but significant $\mathrm{G} \times$ $\mathrm{Y}(P=0.005)$ and $\mathrm{G} \times \mathrm{Y} \times \mathrm{L}(P \leq 0.001)$ interactions suggested that fruit firmness is more dependent on the unpredictable component (i.e., year to year) of environmental variation (Table 4 ). The higher $\mathrm{G} \times \mathrm{E}$ contribution to the total variation compared with the $\mathrm{G}$ component indicated that SSC varied over environments. This higher variation was attributed more to $\mathrm{G} \times \mathrm{Y}$ than to $\mathrm{G} \times \mathrm{L}(8 \%$ vs. $4 \%$ ). These results indicated that SSC was more affected by the unpredictable environmental fluctuations $(\mathrm{G} \times \mathrm{Y})$. Similarly, Dia et al. (2016b) also reported that $\mathrm{G} \times \mathrm{Y}$ had 

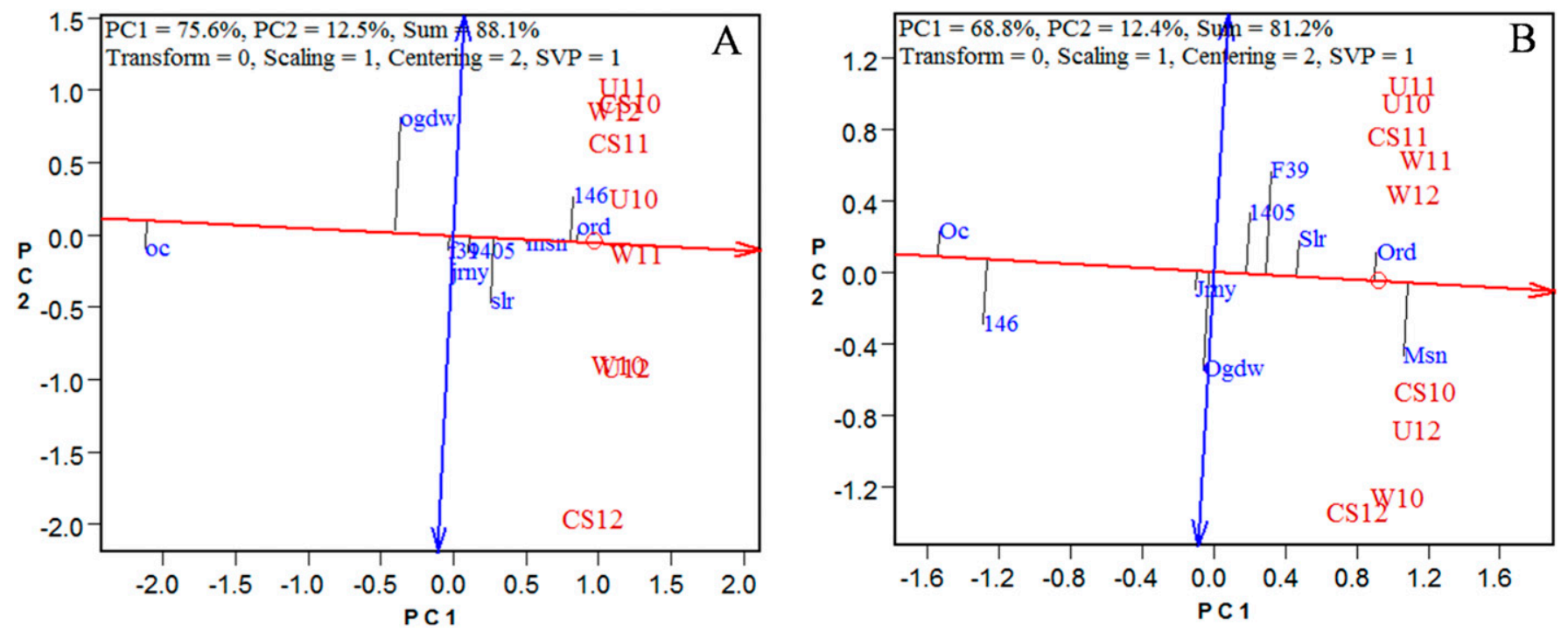

Fig. 6. Average coordination view of biplot for $\beta$-carotene (A) and vitamin C (B). Genotype and environment codes are mentioned in Table 1.

significant effect on sugar content of watermelon, while $\mathrm{G} \times \mathrm{L}$ did not influence watermelon sweetness. However, Kultur et al. (2001) reported significant impact of $\mathrm{G} \times \mathrm{L}$ interaction on percent sugar in fruit juice. The sugar accumulation in muskmelon depends upon the translocation of photo-assimilates from the leaves during fruit ripening (Hubbard et al., 1990). Thus, the silty clay soil with higher water-holding capacity at the Uvalde location, coupled with a longer growing cycle, might have caused more canopy growth and higher total crop photosynthesis, which resulted in higher SSC at this location (Table 5).

Similar trends were observed for $\beta$-carotene, with $27 \%$ of variation attributable to $G \times$ E. However, G contributions (54\%) to the total variation were highly significant for $\beta$-carotene, suggesting high heritability of this trait in melons. Crosby et al. (2007) also reported that carotenoid content changed with the flesh color and ranged from 0 in white-fleshed to $40 \mu \mathrm{g} \cdot \mathrm{g}^{-1}$ in dark-orangefleshed genotypes, with cultivars TAM Uvalde and Mission having more than 36 $\mu \mathrm{g} \cdot \mathrm{g}^{-1}$ carotenoid content. Lester and Eischen (1996) reported a genotypic and environment interaction impact on $\beta$-carotene content of melon fruit. They also mentioned that $\beta$-carotene content was not significantly correlated with moisture content of the mesocarp tissue. Thus, the higher rainfall at College Station and Weslaco, particularly in 2010 and 2012 (Table 1), might have reduced SSC but maintained higher $\beta$-carotene at College Station (Table 5). Similarly, in watermelon, $G \times$ $\mathrm{L}$ interactions did not have any significant impact on lycopene content, indicating that this trait does not vary across locations (Dia et al., 2016b).

Although $\mathrm{G} \times \mathrm{E}$ interactions for vitamin $\mathrm{C}$ content were significant $(P=0.021), \mathrm{G} \times \mathrm{L}, \mathrm{G} \times$ $\mathrm{Y}$, and $\mathrm{G} \times \mathrm{L} \times \mathrm{Y}$ interactions were not significant for this quality trait. This result suggests that the vitamin $\mathrm{C}$ concentrations in the melon fruits were independent of genotype-by-location or genotype-by-year interaction effects. Thus, the genotypes can be selected for vitamin $\mathrm{C}$ content at any of the three locations. Similarly, Lee et al. (2005) observed no $\mathrm{G} \times \mathrm{E}$ interactions for lutein or quercetin content in peppers. In general, the Uvalde location can be used for production of melons rich in vitamin $\mathrm{C}$ content.

Biplot analysis of fruit firmness indicated that Orange Dew was an ideal genotype, while TAMU OC was the most unstable genotype for fruit firmness. Both these genotypes have been selected from crosses between orangefleshed reticulatus, and green- or whitefleshed inodorus-type melons (Lester, 2008); thus, these genotypes inherited the higher firmness from the inodorus group. The instability of TAMU OC can be attributed to its specific adaptation to the College Station and Weslaco locations. Among the cantaloupe genotypes, Mission, followed by TAMU 146, had a good stability, with an aboveaverage firmness (Fig. 5A). Furthermore, both TAMU 146 and 1405 were better than the commercial genotypes, Sol Real and Oro Duro. The latter was the second-ranking genotype for TFY and the first-ranking for $\beta$-carotene content; however, this genotype had low firmness as its most negative fruitquality attribute.

Orange Dew was identified as the ideal genotype for SSC (Fig. 5B). Like firmness, TAMU OC showed specific adaption to the Weslaco location for SSC. The suitability of the Uvalde location for cultivar evaluations for SSC can be attributed to greater differences between day and night temperatures (i.e., $12.3,10.3$, and $9.3{ }^{\circ} \mathrm{C}$ for Uvalde, Weslaco, and College Station, respectively), which might have resulted in higher photosynthesis and lower respiration, and thus the accumulation of more sugars. Yadav and Ram (2010) also reported that three melon genotypes were specially adapted for SSC under favorable environments.
Oro Duro, followed by TAMU 146, was the ideal genotype for $\beta$-carotene content, while inodorus-type TAMU OC, followed by Orange Dew, ranked the lowest for mean $\beta$-carotene content. Lester and Eischen (1996) reported that Mission had higher $\beta$-carotene content than Cristobal, Primo, Cruiser, and Tasty sweet genotypes, and that Mission was considered a stable genotype for $\beta$-carotene across the years. In the current study, Mission was the most stable, with $\beta$-carotene content higher than the grand mean. Thus high and stable $\beta$-carotene contents can be attained in melons through adequate cultivar selections (Lester and Eischen, 1996). In 2010, Weslaco was the most ideal environment for $\beta$-carotene evaluation; but due to temporal fluctuations, more years of testing is required to confirm these results.

Mission was identified as the ideal genotype for vitamin $\mathrm{C}$ content. TAMU breeding lines TAMU 1405 and TAMU F39 also had vitamin $\mathrm{C}$ contents higher than the grand mean. No specific genotypic adaptions were observed for vitamin $\mathrm{C}$ content across environments. Where $\mathrm{G} \times \mathrm{E}$ interactions do not follow a recognizable pattern over years or locations, then the target environment is a single mega-environment in which GEI effects cannot be predicted (Yan and Tinker, 2006). Thus, for vitamin $C$, all the three locations can be considered as a mega-environment.

In conclusion, yield and yield components were mostly affected by $\mathrm{E}$ and $\mathrm{G} \times \mathrm{E}$ interactions. The $\mathrm{G} \times \mathrm{E}$ component of variance was higher than $G$, except for average fruit weight. Furthermore, the significant spatial $(\mathrm{G} \times \mathrm{L})$ interactions for yield traits suggests the possibility to develop location specific cultivars. However, the temporal fluctuations in productivity emphasizes the need to select year-to-year stable cultivars for target environments. The characterization of $\mathrm{G} \times \mathrm{E}$ interactions for fruit-quality traits (e.g., $\beta$-carotene and firmness) can provide greater 
gains than in traits typically influenced by the environment, such as fruit yield and vitamin $\mathrm{C}$ content. This study confirms the general regional adaptability of the most popular commercial cv. Mission at the time of this study. Texas A\&M AgriLife breeding lines show potential for use in the development of high yield, with high fruit quality. The findings of this study also reinforce the idea of identifying optimum environments which best represent the target environment for melon cultivar screening and selections.

\section{Literature Cited}

Bhella, H.S. 1985. Muskmelon growth, yield, and nutrition as influenced by planting method and trickle irrigation. J. Amer. Soc. Hort. Sci. 110:793-796.

Bouwkamp, J.C., F.F. Angell, and F.D. Schales. 1978. Effects of weather conditions on soluble solids of muskmelon. Scientia Hort. 8:265-271.

Cattivelli, L., F. Rizza, F.W. Badeck, E. Mazzucotelli, A.M. Mastrangelo, E. Francia, C. Marè, A. Tondelli, and A.M. Stanca. 2008. Drought tolerance improvement in crop plants: An integrated view from breeding to genomics. Field Crops Res. 105:1-14.

Crosby, K., J. Jifon, L. Pike, and K.S. Yoo. 2007. Breeding vegetables for optimum levels of phytochemicals. Acta Hort. 744:219-224.

Dhakare, B.B. and T.A. More. 2008. Genotype $\times$ environmental interaction of muskmelon with special reference to earliness, yield and yield contributing traits. Indian J. Hort. 65:158-162.

Dia, M., T.C. Wehner, G.W. Elmstrom, A. Gabert, J.E. Motes, J.E. Staub, G.E. Tolla, and I.E. Widders. 2018. Genotype $\times$ environment interaction for yield of pickling cucumber in 24 U.S. environments. Open Agr. 3:1-16.

Dia, M., T.C. Wehner, R. Hassell, D.S. Price, G.E. Boyhan, S. Olson, S. King, A.R. Davis, and G.E. Tolla. 2016a. Genotype $\times$ environment interaction and stability analysis for watermelon fruit yield in the United States. Crop Sci. 56:1645-1661.

Dia, M., T.C. Wehner, P. Perkins-Veazie, R. Hassell, D.S. Price, G.E. Boyhan, S.M. Olson, S.R. King, A.R. Davis, G.E. Tolla, J. Bernier, and B. Juarez. 2016b. Stability of fruit quality traits in diverse watermelon cultivars tested in multiple environments. Hort. Res. 3:16066.

Edmonds, J.B. and F.J. McFall. 1927. Influence of certain varietal and cultural treatments on the sugar content of cantaloupes. Proc. Amer. Soc. Hort. Sci. 24:72-75.

Hubbard, N.L., D.M. Pharr, and S.C. Huber. 1990. Sucrose metabolism in ripening muskmelon fruit as affected by leaf area. J. Amer. Soc. Hort. Sci. 115:798-802.
Jamshidmoghaddam, M. and S.S. Pourdad. 2012. Genotype $\times$ environment interactions for seed yield in rainfed winter safflower (Carthamus tinctorius L.) multi-environment trials in Iran. Euphytica 190:357-369.

Joshi, B.K., R.G. Gardner, and D.R. Panthee. 2011 GGE biplot analysis of tomato $F_{1}$ hybrids evaluated across years for marketable fruit yield. J. Crop Improv. 25:488-496.

Kang, M.S. 2002. Quantitative genetics, genomics, and plant breeding. CABI, New York.

Kultur, F., H.C. Harrison, and J.E. Staub. 2001. Spacing and genotype affect fruit sugar concentration, yield, and fruit size of muskmelon. HortScience 36:274-278.

Lee, J.J., K.M. Crosby, L.M. Pike, K.S. Yoo, and D.I. Leskovar. 2005. Impact of genetic and environmental variation on development of flavonoids and carotenoids in pepper (Capsicum spp.). Scientia Hort. 106:341-352.

Leskovar, D.I., S. Goreta, and J.A. Franco. 2006 Impact of AVG preharvest spray and soil injection on yield and quality of melon. HortScience 41:1249-1252.

Lester, G.E. 2006. Consumer preference quality attributes of melon fruits. Acta Hort. 712:175182.

Lester, G.E. 2008. Antioxidant, sugar, mineral, and phytonutrient concentrations across edible fruit tissues of orange-fleshed honeydew melon (Cucumis melo L.). J. Agr. Food Chem. 56:3694-3698.

Lester, G.E. and K.M. Crosby. 2002. Ascorbic acid, folic acid, and potassium content in postharvest green-flesh honeydew muskmelons: Influence of cultivar, fruit size, soil type, and year. J. Amer. Soc. Hort. Sci. 127:843-847.

Lester, G.E. and F. Eischen. 1996. Beta-carotene content of postharvest orange-fleshed muskmelon fruit: Effect of cultivar, growing location and fruit size. Plant Foods Hum. Nutr. 49:191-197.

Lester, G.E. and M.A. Grusak. 2004. Field application of chelated calcium: Postharvest effects on cantaloupe and honeydew fruit quality. HortTechnology 14:29-38.

Li, Z., L. Yao, Y. Yang, and A. Li. 2006. Transgenic approach to improve quality traits of melon fruit. Scientia Hort. 108:268-277.

McIntosh, M.S. 1983. Analysis of combined experiments. Agron. J. 75:153-155.

Paris, M.K., J.E. Zalapa, J.D. McCreight, and J.E. Staub. 2008. Genetic dissection of fruit quality components in melon (Cucumis melo L.) using a RIL population derived from exotic $\times$ elite US Western Shipping germplasm. Mol. Breed. 22:405-419.

Park, S.O., K.M. Crosby, and K.S. Yoo. 2006. Confirmation of RAPD markers associated with QTL for ascorbic acid in melon. Subtrop. Plant Sci. 58:18-22.
Pitrat, M. 2016. Melon genetic resources: Phenotypic diversity and horticultural taxonomy, $\mathrm{p}$. 25-60. In: R. Grumet, N. Katzir, and J. GarciaMas (eds.). Genetics and genomics of cucurbitaceae. Springer International Publishing, Cham, Switz.

Sadler, G., J. Davis, and D. Dezman. 1990. Rapid extraction of lycopene and $\beta$-carotene from reconstituted tomato paste and pink grapefruit homogenates. J. Food Sci. 55:1460-1461.

Sharma, S.P., D.I. Leskovar, and K.M. Crosby. 2019. Genotypic differences in leaf gas exchange and growth responses to deficit irrigation in reticulatus and inodorus melons (Cucumis melo L.). Photosynthetica 57:237247.

Sharma, S.P., D.I. Leskovar, K.M. Crosby, A. Volder, and A.M.H. Ibrahim. 2014. Root growth, yield, and fruit quality responses of reticulatus and inodorus melons (Cucumis melo L.) to deficit subsurface drip irrigation. Agr. Water Mgt. 136:75-85.

Villanueva, M. 2004. Compositional changes during ripening of two cultivars of muskmelon fruits. Food Chem. 87:179-185.

Wimalasiri, P. and R.B. Wills. 1983. Simultaneous analysis of ascorbic acid and dehydroascorbic acid in fruit and vegetables by highperformance liquid chromatography. J. Chromatography 256:368-371.

Wolf, D.W., E.M. Miller, and C. Lander. 1994. Genotype $\times$ environment interactions of muskmelon hybrids for yield and fruit size. HortScience 29:S450.

Yadav, R.K. and H.R. Ram. 2010. Stability analysis in muskmelon (Cucumis melo L.). Veg. Sci. 37:35-39.

Yan, W. 2001. GGE biplot-A Windows application for graphical analysis of multienvironment trial data and other types of two-way data. Agron. J. 93:1111-1118.

Yan, W., P. Cornelius, J. Crossa, and L.A. Hunt. 2001. Two types of GGE biplots for analyzing multi-environment trial data. Crop Sci. 41:656663.

Yan, W., L. Hunt, Q. Sheng, and Z. Szlavnics. 2000. Cultivar evaluation and mega-environment investigation based on the GGE biplot. Crop Sci. 40:597-605.

Yan, W. and M.S. Kang. 2002. GGE biplot analysis: A graphical tool for breeders, geneticists, and agronomists. CRC Press, Boca Raton, FL.

Yan, W. and N.A. Tinker. 2006. Biplot analysis of multi-environment trial data: Principles and applications. Can. J. Plant Sci. 86:623-645.

Zalapa, J.E., J.E. Staub, and J.D. McCreight. 2006. Generation means analysis of plant architectural traits and fruit yield in melon. Plant Breed. 125:482-487. 